\title{
Changes in the pancreas caused by different types of hypertension
}

\author{
Paulina Nowińska and Irena Kasacka ${ }^{\bowtie}$ \\ Department of Histology and Cytophysiology, Medical University of Bialystok, Białystok, Poland
}

\begin{abstract}
Hypertension is considered a lifestyle disease. Unfavorable forecasts predict a significant increase in the number of patients suffering from this disorder. Many changes in various organs have been observed as a result of ischemia. An interesting question arises of whether differences between the mechanisms occurring in different types of hypertension could produce different effects in the organs. It is well known that there is a close relationship between hypertension and insulin resistance. On the other hand, insulin resistance is the main cause of type 2 diabetes, which develops in parallel with changes in the pancreas. The pancreas is a very important organ since it produces enzymes crucial for the digestive process, as well as performs an important endocrine function. The work presented here focuses primarily on the latter issue. The authors present an overview of contemporary literature concerning the influence of different types of hypertension on the function of the pancreas.
\end{abstract}

Key words: pancreas, hypertension

Received: 09 January, 2017; revised: 21 August, 2017; accepted: 22 October, 2017; available on-line: 30 November, 2017

e-mail: kasacka@umb.edu.pl

Abbreviations: aSMA, alpha-smooth muscle actin; Ang II, angiotensin II; AT2, angiotensin II receptor type 2; CgA, chromogranin A; EMT, epithelial-to-mesenchymal transition; PST, pancreastatin; SHR, spontaneously hypertensive rats; SHRsp, stroke prone spontaneously hypertensive rats; WKY, Wistar-Kyoto rats; ZDF, zucker diabetic rats

\section{INTRODUCTION}

Hypertension is a major disease of the circulatory system and its complications are a primary cause of mortality worldwide. According to WHO, the number of people suffering in the year of 2000 from hypertension worldwide was estimated at 972 million. It is expected that after 2025 it will exceed the number of 1.5 billion. Smokers, obese individuals, those abusing salt and the elderly are particularly at risk. However, lifestyle changes have resulted in a growing number of young people being affected by the condition. Treatment of the disease frequently involves symptom elimination without a prior diagnosis of the exact cause (Kearney et al., 2005).

Several studies have demonstrated numerous changes in various organs which result from ischemia in hypertension (Cohuet et al., 2006; Hsueh et al., 1992). It has been also shown that high blood pressure increases the ability of tumors to metastasize (Djamgoz, 2015; Li et al., 2015).

The pancreas is a special gland of the digestive system which produces enzymes crucial for the digestive process. Pancreatic islets are groupings of endocrine cells which produce a number of hormones. Two of them, insulin and glucagon, play a fundamental role in carbohydrate metabolism regulation since they are the main hormones involved in this process (Ma et al., 2015; Lukens, 1959). Several reports published to date illustrate the impaired function of pancreatic islets in hypertension, although the exact mechanism is still not fully understood (Satoh et al., 2014; Tran et al., 2009).

Here, we present an overview of contemporary literature concerning the influence of different types of hypertension on the function of the pancreas.

\section{TYPES OF HYPERTENSION}

Hypertension can be divided into a primary (also referred to as essential) and a secondary variety. Essential hypertension is thought to have genetic basis in the majority of cases, although environmental causes are believed to be the triggering factors. In experimental studies on animals, spontaneously hypertensive rats (SHR), stroke prone spontaneously hypertensive rats (SHRsp) and zucker diabetic fatty rats (ZDF) are used. Secondary hypertension is a consequence of the action of certain factors, such as renal ischemia, excessive salt/carbohydrate (fructose)/fat intake, the intake of angiotensin 2, erythropoietin, nitric oxide inhibitor (cadmium chloride) or deoxycorticosterone acetate. Experimental models used most frequently include renovascular hypertension (2K1C, two kidney-one clip), fructose-induced hypertension and angiotensin 2 induced hypertension. The control group usually comprises Wistar, Wistar-Kyoto or Sprague-Dawley rats (Chen et al., 2015; Ogihara et al., 2002; Sechi et al., 1992; Shehata, 2008).

\section{OVERALL IMPACT OF HYPERTENSION ON PANCREAS BY INSULIN RESISTANCE}

Establishment of the existence of the metabolic syndrome, comprising hypertension, dyslipidemia, hyperglycemia and obesity, has confirmed a close relationship between hypertension and glucose metabolism (Abuissa et al., 2005; Ferrannini \& Cushman, 2012; Landsberg \& Krieger, 1989; Sowers et al., 2001). Insulin resistance is presumably the body's response designed to prevent weight gain in individuals with hypertension (Landsberg \& Krieger, 1989). A positive correlation between RAAS activation and insulin resistance has been observed in rats with primary hypertension and in hypertensive patients in clinical trials (Landsberg \& Krieger, 1989; Giner et al., 2001; Luther \& Brown, 2011). However, recent studies have not demonstrated a significant correlation between renovascular hypertension in rats and insulin sensitivity (Matayoshi et al., 2007; Cheung et al., 2012 ). 


\section{INSULIN RESISTANCE AND CHANGES IN THE B CELL FUNCTION}

The phenomenon of insulin resistance is known to be crucial for the mechanism leading to type 2 diabetes mellitus (Khodabandehloo et al., 2016; Kinalska, 2001). During the first phase of insulin resistance, insulin secretion increases. This mechanism allows the body to maintain the blood glucose level within the normal range, but even at this stage a number of more sensitive tests can detect the abnormal function of $\beta$-cells. These changes intensify and the $\beta$-cell function constantly deteriorates. When they are no longer able to compensate for reduced insulin sensitivity, hyperglycemia occurs. In addition, it is known that as a result of an elevated blood insulin level following stimulation of the sympathetic nervous system, hypertrophy of vascular muscles and sodium retention increase, which leads to an increase in blood pressure (Khodabandehloo et al., 2016; Prentki \& Nolan, 2006). In full-blown diabetes, the insulin resistance level stabilizes, but insulin secretion and the $\beta$-cell function deteriorates further. At the beginning, abnormalities are related to the first phase of insulin secretion; some data indicate that is possible to recreate this stage provided that the patient keeps strict metabolic control (Małecki, 2006; Małecki \& Klupa, 2007; Prentki \& Nolan, 2006). Subsequently, insulin secretion is delayed and reduced, and after many years of illness it is maintained at a very low level. The mechanism of reducing insulin secretion occurs as a result of two phenomena: a reduction in the $\beta$-cell mass and their abnormal function. Autopsies of deceased diabetic patients, as well as animal model studies have demonstrated a decrease in the size of $\beta$ cells by $30-50 \%$ and the presence of amyloid plaques (Andronico et al., 2002; Bhanot \& McNeill, 1996; Kahn, 2003).

\section{ESSENTIAL HYPERTENSION}

When all known causes of hypertension have been excluded and blood pressure remains high, essential hypertension, otherwise known as spontaneous or primary, is diagnosed. It is estimated that this type of hypertension affects $90-95 \%$ of all hypertensive patients (Chahoud et al., 2014; Cooper et al., 1992; Kochueva et al., 2014; Ma et al., 2015).

Male rats with hypertension, also known as SHR, constitute an appropriate model for experimental studies regarding the effects of hypertension on different organs. As previously mentioned, apart from SHR rats, SHRsp and ZDF rat models are used (Buchanan et al., 1992; Penesova et al., 2011; Satoh et al., 2014).
Satoh and coworkers (2014) had conducted research including the assessment of hypertension-induced morphological changes in the pancreatic islets of SHRsp. This study had demonstrated that the size of the islets was significantly greater in the SHRsp than in the WKY rats from the control group. In addition, the parameter of hypertension-related vascular damage (wall-to-lumen ratio) was significantly higher in the SHRsp than in the WKY rats.

Furthermore, that study had investigated an epithelial-to-mesenchymal transition (EMT). In this process epithelial cells lose their cell polarity and cell connections between adhering cells, and obtain migratory and invasive properties to become mesenchymal stem cells. At this time they become multipotent stromal cells and they are able to differentiate into a number of cell types. This process has been observed in wound healing, organ fibrosis and metastasis initiation in cancer progression. In an experiment conducted by Satoh et al. (2014), EMT was determined by immunofluorescent staining for alpha-smooth muscle actin ( $\alpha \mathrm{SMA})$ and vimentin in the islets. The stained area was also significantly larger in the SHRsp in comparison with the WKY rats.

Buchanan and coworkers (1992) in their study of young SHR rats found excessive stimulation of the pancreatic $\beta$-cells, independent of insulin resistance (Table 1). The level of insulin response to intravenous glucose injections in the SHR was 2-3 times higher than in the WKY rats, which resulted in an accelerated decline in the glucose level in the study group.

\section{SECONDARY HYPERTENSION}

Secondary hypertension occurs in about $10 \%$ of population with hypertension. Studies on different types of secondary hypertension most frequently use male Wistar or Sprague-Dawley rats. The rats are subjected to the action of specific factors in order to obtain the desired type of hypertension. Both models are free of a genetic load and they are the perfect research material (Kasacka et al., 2015; Matayoshi et al., 2007).

\section{RENOVASCULAR HYPERTENSION}

Renovascular hypertension is the most common type of secondary hypertension. It is caused by the stenosis of one or both renal arteries, which results in increased renin production by the ischemic kidney. Therefore, it is believed that the cause of this type of hypertension is potentially eradicable (Davis et al., 1979; Martinez-Maldonado, 1991).

Table 1. Characteristic changes occurring in pancreas in hypertension

\begin{tabular}{|c|c|c|}
\hline \multicolumn{2}{|c|}{ Type of hypertension } & \multirow{2}{*}{$\begin{array}{l}\text { Changes in pancreas } \\
\text { increase in the size of pancreatic islets, } \\
\beta \text {-cells' hyperactivity, } \\
\text { elevated EMT and blood vessel damage }\end{array}$} \\
\hline$\stackrel{\substack{\frac{\pi}{\pi} \\
\frac{\pi}{2}}}{\frac{1}{2}}$ & Primary & \\
\hline \multirow{3}{*}{ 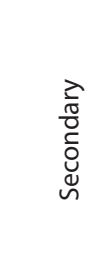 } & Renovascular hypertension & $\begin{array}{l}\text { reduction in the number of } a \text { and CART- positive cells, } \\
\text { no changes in the number and intensity of } \beta \text { cell staining, } \\
\text { reduction in the biosynthesis of CgA and PST }\end{array}$ \\
\hline & Fructose-induced hypertension & $\begin{array}{l}\text { decrease in the number of pancreatic islets and the mass and surface of } \\
\beta \text {-cells, } \\
\text { increase in the number of apoptotic } \beta \text { cells, }\end{array}$ \\
\hline & Angiotensin II-induced hypertension & $\begin{array}{l}\text { reduction in the weight and capacity of } \beta \text {-cells as a result of increased insulin } \\
\text { secretion }\end{array}$ \\
\hline
\end{tabular}


The Goldblatt model, also known as the two-kidney, one-clip (2K1C) model, is the model most frequently used in renovascular hypertension studies. In 1934 Dr. Goldblatt observed that a reduction of blood flow in one kidney caused by squeezing of the artery led to an increase in blood pressure. When the clasp was released, the blood pressure returned to its normal level (Okamura et al., 1986; Piotrowska et al., 2016).

RAAS stimulation constitutes the main pathological mechanism of renovascular hypertension. Systemic and local narrowing of blood vessels, caused by RAAS hormones, restricts blood flow to the pancreas leading to hypoperfusion and ischemia. These processes induce an increase in the secretion of nitric oxide (NO) and reactive oxygen species which reduce the lifespan of insulin-producing cells. Angiotensin II can also affect $\beta$ cells, demonstrating a pro-apoptotic effect (Davis et al., 1979; Martinez-Maldonado, 1991).

Kasacka and coworkers (2015) performed immunohistochemical studies designed to evaluate cells containing insulin, glucagon and CART (cocaine and amphetamine regulated transcript) in the pancreas of rats with renovascular hypertension. These studies had shown a reduction in the number of cells containing glucagon and an increase in the number and immunoreactivity of CART-positive cells. However, no changes in the number or intensity of the $\beta$-cell response were observed.

Studies on effects of renovascular hypertension on islet cells containing chromogranin A (CgA) and pancreastatin (PST) in rats have demonstrated the presence of CgA- and PST-IR cells in the entire area of the islands, but the reaction intensity varied (Piotrowska et al., 2016). The highest reaction intensity was found in the perimeter of the islands, i.e. in the area where $\alpha$ cells are located. The intensity of immunohistochemical reaction in the cells found in the central part of the islands (significant predominance of $\beta$ cells) was much weaker. The authors indicated significant differences in the intensity of cell immunoreactivity in the pancreas of hypertensive rats in comparison with the animals from the control group. The study results suggest a reduction in the biosynthesis of CgA and PST in the pancreas of hypertensive rats, which may indicate the participation of these peptides in disturbing the gland's function under elevated pressure (Piotrowska et al., 2016) (Table 1).

\section{RENOVASCULAR HYPERTENSION (MALIGNANT)}

Results of a comprehensive study conducted by Pagel and Woolf (1948) and Guerrea and coworkers (2001) on the consequences of malignant hypertension revealed that a particularly high percentage $(30 \%)$ of patients with malignant hypertension had renovascular hypertension. It was also found that aseptic necrosis of the pancreas caused by arterial thrombosis was a possible, although rare, complication of malignant hypertension. In histopathological studies, the pancreas had shown an extensive, but sharply demarcated, areas of anaemic necrosis. In their central part, the tissue was liquefied as a consequence of the action of digestive enzymes. At the border of these areas there was a narrow haemorrhagic zone surrounding the necrotic focus (Pagel \& Woolf, 1948).

\section{FRUCTOSE-INDUCED HYPERTENSION}

Studies have shown that an excessive intake of fructose induces an increase in blood pressure in rats, associated with elevated glucose and triglyceride levels, as well as insulin resistance. Chronic fructose abuse enhances negative metabolic effects, such as the metabolic syndrome. Experimental studies in this field are generally conducted on the Wistar and Sprague-Dawley rats whose diet contains $66 \%$ fructose. The control groups in such studies are composed of rats fed a standard diet (Dai \& McNeill, 1995; Damiano et al., 2002; Reaven et al., 1989).

In 1987 Hwang et al., published the results of their research which found that insulin resistance, as well as parameters such as hyperinsulinemia and hypertriglyceridemia, occurred at a relatively short time after introduction of the fructose-enriched diet and evolved in parallel with the development of hypertension. The authors associated the development of hypertension with increased activation of the sympathetic nervous system and synthesis of catecholamines, not excluding the participation of insulin resistance and hyperinsulinemia.

Studies conducted with Wistar rats fed a fructose-rich diet demonstrated a fall in the number of pancreatic islets, the total endocrine surface area, the surface and mass of $\beta$-cells and the $\beta$ cell/islands ratio. In addition, the number of apoptotic $\beta$ cells in the tested animals was found to be $44 \%$ higher than in the control group (Maiztegui et al., 2009) (Table 1).

A similar experimental model demonstrated a reduction in the number of insulin receptors in the liver and skeletal muscle of the Sprague-Dawley rats with fructoseinduced hypertension. The authors of this study speculated that this may have an impact on the development of insulin resistance and may lead to morphological and functional changes in the pancreas (Catena et al., 2003).

\section{ANGIOTENSIN 2 -INDUCED HYPERTENSION}

In order to obtain this model of hypertension, research subjects are exposed to the effects of angioten$\sin 2$ (Ang II). The dose needed to achieve the effect is calculated per kilogram of body weight/day. It is known that specific angiotensin II receptor type 2 (AT2) binding sites are detected within the pancreas, including the islet cells, acinar cells, duct cells, pancreatic vasculature, and epithelia of the pancreatic ductal system (Carlsson et al., 1998; Gletsu et al., 2005).

In vitro studies conducted by Dunning and coworkers (1984) on isolated pancreatic islets did not show a significant effect of angiotensin 2 on insulin secretion. The authors speculated that the study results could have been related to a lack of blood supply and innervation of the islands, which may have significantly affected their response.

However, when examining $\beta$ cells (line MIN6) secretory activity in a medium with varying concentrations of glucose, Gletsu and coworkers (2005) had found that insulin secretion increased together with an increase in glucose concentration in the medium. In addition, in an experiment by the same authors, mice that were administered angiotensin 2 for 4 weeks had a significantly higher plasma insulin concentration after glucose stimulation, compared to saline treated mice.

Other studies (Carlsson et al., 1998) had also shown an enhanced insulin secretion in the pancreas of the Sprague-Dawley rats under the effect of angiotensin 2 . Furthermore, the authors demonstrated an Ang II dosedependent decrease in blood flow in all areas of the pancreas (Table 1).

An increase in insulin secretion occurs via several different mechanisms, one of them being a reduction in peripheral blood flow. Administration of angiotensin 2 also 
results in enhanced glucose clearance. Studies show that Ang II also affects the insulin signaling pathway by escalating serine phosphorylation in insulin receptors located in the smooth muscle of the aortic wall, thus reducing its activity. There is also evidence that Ang II alters the function of other mediators of the insulin signaling pathway (Carlsson et al., 1998; Gletsu et al., 2005).

\section{HYPERTENSION - CLINICAL TRIALS}

Clinical trials are usually conducted on patients with hypertension whose precise cause has not been specified.

In order to answer the question of whether there is a link between hypertension and type 2 diabetes, Gress and coworkers (2000) performed clinical trials whose results demonstrated that type 2 diabetes occurs 2.5 times more frequently in patients with hypertension when compared to people with normal blood pressure. This confirms the hypothesis about the effect hypertension can exert on the development of insulin resistance and the function of pancreatic islets, including human islets.

Other studies designed to evaluate the relationship between changes in fasting insulin levels and the possible development of hypertension in healthy individuals (without hypertension and diabetes) had shown that a high and continually increasing base level of insulin is associated with the development of hypertension within 4 years (Park et al., 2013).

\section{CONCLUSIONS}

The overview of the literature demonstrates that different types of hypertension have different effects on the function of the pancreas.

A comparative analysis of the results of published studies indicates significant differences between the changes occurring in the pancreas under the conditions of hypertension of various etiologies.

Considering the fact that hypertension has been recognized as a lifestyle disease and unfavorable forecasts predict a significant rise in the incidence of hypertension, a closer examination of its mechanisms of development and impact on various organs is warranted.

\section{REFERENCES}

Abuissa H, Jones PG, Marso SP, O’Keefe JH (2005) Angiotensin-converting enzyme inhibitors or angiotensin receptor blockers for prevention of type 2 diabetes: a meta-analysis of randomized clinical trials. J Am Coll Cardiol 46: 821-826. http://dx.doi.org/10.1016/j. jacc. 2005.05.051

Andronico G, Ferraro-Mortellaro R, Mangano MT, Romé M, Raspanti F, Pinto A, Licata G, Seddio G, Mulé G, Cerasola G (2002) Insulin resistance and glomerular hemodynamics in essential hypertension. Kidney Int 62: 1005-1009. http://dx.doi.org/10.1046/j.15231755.2002.00529.x

Bhanot S, McNeill JH (1996) Insulin and hypertension: a causal relationship? Cardiovasc Res 31: 212-221. http://dx.doi.org/10.1016/ S0008-6363(95)00218-9

Buchanan TA, Youn JH, Campese VM, Sipos GF (1992) Enhanced glucose tolerance in spontaneously hypertensive rats: pancreatic $\beta$-cell hyperfunction with normal insulin sensitivity. Diabetes 41: 872-878. http://dx.doi.org/10.2337/diab.41.7.872

Carlsson PO, Berne C, Jansson L (1998) Angiotensin II and the endocrine pancreas: effects on islet blood flow and insulin secretion in rats. Diabetologia 41: 127-133. http://dx.doi. org/10.1007\%2Fs001250050880

Catena C, Giacchetti G, Novello M, Colussi G, Cavarape A, Sechi LA (2003) Cellular mechanisms of insulin resistance in rats with fructose-induced hypertension. Am J Hypertens 16: 973-978. http://dx. doi.org/10.1016/S0895-7061(03)01002-1
Chahoud J, Mrad J, Semaan A, Asmar R (2014) Prevalence of diabetes mellitus among patients with essential arterial hypertension. J Med Liban 63: 74-80

Chen AX, Jerums G, Baqar S, Lambert E, Somarajah G, Thomas G, O'Callaghan Ch, MacIsaac RJ, Ekinci EI (2015) Short-term dietary salt supplementation blunts telmisartan induced increases in plasma rennin activity in hypertensive patients with type 2 diabetes mellitus. Clin Sci (Lond) 129: 415-422. http://dx.doi.org/10.1042/ CS20140536

Cheung BM, Li C (2012) Diabetes and hypertension: is there a common metabolic pathway? Curr Atheroscler Rep 14: 160-166. http:// dx.doi.org/10.1007\%2Fs11883-012-0227-2

Cohuet G, Struijker-Boudier H (2006) Mechanisms of target organ damage caused by hypertension: therapeutic potential. Pharmacol Ther 111: 81-98. http://dx.doi.org/10.1016/j.pharmthera.2005.09.002

Cooper ME, Rumblejon R, Allen TJ, O’brien RC, Jerums G, Doyle AE (1992) Antihypertensive therapy in a model combining spontaneous hypertension with diabetes. Kidney Int 4: 898-903. http:// dx.doi.org/10.1038/ki.1992.137

Dai S, McNeill JH (1995) Fructose-induced hypertension in rats is concentration- and duration-dependent. J Pharmacol Toxicol Methods 33: 101-107. http://dx.doi.org/10.1016/1056-8719(94)00063-A

Damiano P, Cavallero S, Mayer M, Rosón MI, de la Riva I, Fernández B, Puyó AM (2002) Impaired response to insulin associated with protein kinase $\mathrm{c}$ in chronic fructose-induced hypertension. Blood Press 11: 345-351

Davis BA, Crook JE, Vestal RE, Oates JA (1979) Prevalence of renovascular hypertension in patients with grade III or IV hypertensive retinopathy. $N$ Engl J Med 301: 1273-1276. http://dx.doi. org/10.1056/NEJM197912063012307

Djamgoz MB (2015) Blood pressure and risk of cancer progression - A possible connection with salt and voltage-gated sodium channel. Med Hypotheses 85: 591-593. http://dx.doi.org/10.1016/j. mehy.2015.07.021

Dunning BE, Moltz JH, Fawcett CP (1984) Actions of neurohypophysial peptides on pancreatic hormone release. Am J Phys Endo Met 246: 108-114

Ferrannini E, Cushman WC (2012) Diabetes and hypertension: the bad companions. Lancet 380: 601-610. http://dx.doi.org/10.1016/ S0140-6736(12)60987-8

Giner V, Coca A, de la Sierra A (2001) Increased insulin resistance in salt sensitive essential hypertension. J Hum Hypertens 15: 481-485. http://dx.doi.org/10.1038/sj.jhh.1001216

Gletsu N, Doan TN, Cole J, Sutliff RL, Bernstein KE (2005) Angiotensin II-induced hypertension in mice caused an increase in insulin secretion. V ascul Pharmacol 42: 83-92. http://dx.doi.org/10.1016/j. vph.2005.01.006

Gress TW, Nieto FJ, Shahar E, Wofford MR, Brancati FL (2000) Hypertension and antihypertensive therapy as risk factors for type 2 diabetes mellitus. $N$ Engl J Med 342: 905-912. http://dx.doi. org/10.1056/NEJM200003303421301

Guerrera C, Colivicchi F, Pola R, Travaglino F, Filice G, Guerrera G, Melina D (2001) Acute abdominal symptoms in malignant hypertension: clinical presentation in five cases. Clin Exp Hypertens 23: 461-469

Hsueh WA, Anderson PW (1992) Hypertension, the endothelial cell and the vascular complications of diabetes mellitus. Hypertension 20: 253-263. Doi: 10.1161/01.HYP.20.2.253

Hwang IS, Ho H, Hoffman BB, Reaven GM (1987) Fructose-induced insulin resistance and hypertension in rats. Hypertension 10: 512-516. doi: 10.1161/01.HYP.10.5.512

Kahn SE (2003) The relative contributions of insulin resistance and beta-cell dysfunction to the pathophysiology of type 2 diabetes. Diabetologia 46: 3-19. http://dx.doi.org/10.1007\%2Fs00125-002-1009-0

Kasacka I, Janiuk I, Piotrowska Zे (2015) Evaluation of CART-, glucagon-, and insulin immunoreactive cells in the pancreas of anexperimental rat model of unilateral renal arterystenosis. Histol Histopathol 30:445-452. DOI: 10.14670/HH-30.445

Kearney PM, Whelton M, Reynolds K, Muntner P, Whelton PK, He J (2005) Global burden of hypertension: analysis of worldwide data. Lancet 365: 217-223. http://dx.doi.org/10.1016/S01406736(05)17741-1

Khodabandehloo H, Gorgani-Firuzjaee S, Panahi G, Meshkani R (2016) Molecular and cellular mechanisms linking inflammation to insulin resistance and $\beta$-cell dysfunction. Transl Res 167: 228-256. http://dx.doi.org/10.1016/j.trsl.2015.08.011

Kinalska I (2001) Insulin excretion impairment in type 2 diabetes clinical implications. Diabetologia Praktyczna, tom 2, supl. C

Kochueva M, Sukhonos V, Shalimova A, Psareva V, Kirichenko N (2014) State of integral remodeling parameters of target organs in patients with essential hypertension and obesity. Georgian Med News 231: $26-30$

Landsberg L, Krieger DR (1989) Obesity, metabolism, and the sympathetic nervous system. Am J Hypertens 2: 125S-132S. doi:10.1093/ ajh/2.3.125S 
Li D, Mao Y, Chang P, Liu C, Hassan MM, Yeung SJ, Abbruzzese JL (2015) Impacts of new-onset and long-term diabetes on clinical outcome of pancreatic cancer. Am J Cancer Res 5: 3260-3269

Lukens FD (1959) The pancreas: insulin and glucagon. Annu Rev Physiol 21: 445-474. http://dx.doi.org/10.1146/annurev. ph.21.030159.002305

Luther JM, Brown NJ (2011) The renin-angiotensin-aldosterone system and glucose homeostasis. Trends Pharmacol Sci 32: 734-739. http://dx.doi.org/10.1016/j.tips.2011.07.006

Ma L, Feng M, Qian Y, Yang W, Liu J, Han R, Zhu H, Li Y (2015). Insulin resistance is an important risk factor for cognitive impairment in elderly patients with primary hypertension. Yonsei Med J 56: 89-94. http://dx.doi.org/10.3349/ymj.2015.56.1.89

Maiztegui B, Borelli MI, Raschia MA, Del Zotto H, Gagliardino JJ (2009) Islet adaptive changes to fructose-induced insulin resistance: $\beta$-cell mass, glucokinase, glucose metabolism, and insulin secretion. J Endocrinol 200: 139-149. http://dx.doi.org/10.1677/JOE-08-0386

Małecki MT (2006) Obesity - insulin resistance - type 2 diabetes mellitus. Kardiol Pol 64: 561-566 (In Polish?)

Małecki MT, Klupa T (2007) Role of beta-cells in the pathogenesis of diabetes. Diabetologia Praktyczna, tom 8, suplement B (In Polish?)

Martinez-Maldonado M (1991) Pathophysiology of renovascular hypertension. Hypertension 17: 707-719. Doi: 10.1161/01.HYP.17.5.707

Matayoshi T, Kamide K, Takiuchi S, Horio T, Yoshihara F, Nakamura S, Kawano Y (2007) Relationship between insulin resistance and the renin-angiotensin system: analysis for patients with essential and renovascular hypertension. Clin Exp Hypertens 29: 479-487. Doi: $10.1080 / 1064196070161618$

Ogihara T, Asano T, Ando K, Sakoda H, Anai M, Shojima N, Ono H, Onishi Y, Fujishiro M, Abe M, Fukushima Y, Kikuchi M, Fujita $\mathrm{T}$ (2002) High-salt diet enhances insulin signaling and induces insulin resistance in Dahl salt-sensitive rats. Hypertension 40: 83-89. Doi: 10.1161/01.HYP.0000022880.45113.C9

Okamura T, Miyazaki M, Ingami T, Toda N (1986) Vascular Renin-Angiotensin System in Two-Kidney, One Clip Hypertensive Rats. Hypertension 8: 560-565. Doi: 10.1161/01.HYP.8.7.560

Pagel W, Woolf AF (1948) Aseptic necrosis of pancreas due to arterial thrombosis in malignant hypertension. $\mathrm{Br}$ Med J 4548: 442-438
Park SE, Rhee EJ, Park CY, Oh KW, Park SW, Kim SW, Lee WY (2013) Impact of hyperinsulinemia on the development of hypertension in normotensive, nondiabetic adults: a 4-year follow-up study. Metabolism 62: 532-538. http://dx.doi.org/10.1016/j.metabol.2012.09.013

Penesova A, Cizmarova E, Belan V, Blazicek P, Imrich R, Vlcek M, Vigas M, Selko D, Koska J, Radikova Z (2011) Insulin resistance in young, lean male subjects with essential hypertension. I Hum Hypertens 25: 391-400. http://dx.doi.org/10.1038/jhh.2010.72

Piotrowska Ż, Janiuk I, Lewandowska A, Kasacka I (2016) Renovascular hypertensive decrease immunoreactivity of cells containing chromogranin $\mathrm{A}$ and pancreastatin in the pancreas of rats. Histol Histopathol 32:69-75. http://dx.doi.org/10.14670/HH-11-771

Prentki M, Nolan CJ (2006) Islet $\beta$ cell failure in type 2 diabetes. J Clin Invest 116: 1802-1812. http://dx.doi.org/10.1172\%2FJCI29103

Reaven GM, Ho H, Hoffmann BB (1989) Somatostatin inhibition of fructose-induced hypertension. Hypertension 14: 117-120. DOI: 10.1161/01.HYP.14.2.117

Satoh M, Nagasu H, Haruna Y, Ihoriya C, Kadoya H, Sasaki T, Kashihara N (2014) Hypertension promotes islet morphological changes with vascular injury on pre-diabetic status in SHRsp rats. Clin Exp Hypertens 36: 159-164. http://dx.doi.org/10.3109/10641963.2013.80 4539

Sechi LA, Melis A, Tedde R (1992) Insulin hypersecretion: a distinctive feature between essential and secondary hypertension. Metabolism 41: 1261-1266. http://dx.doi.org/10.1016/0026-0495(92)90019-7

Shehata MF (2008) Genetic and dietary salt contributors to insulin resistance in Dahl salt-sensitive (S) rats. Cardiovasc Diabetol 7:1 http:// dx.doi.org/10.1186\%2F1475-2840-7-7

Sowers JR, Epstein M, Frohlich ED (2001) Diabetes, hypertension, and cardiovascular disease an update. Hypertension 37: 1053-1059. Doi: 10.1161/01.HYP.37.4.1053

Tran LT, Yuen VG, McNeill JH (2009) The fructose-fed rat: a review on the mechanisms of fructose-induced insulin resistance and hypertension. Mol Cell Biochem 332: 145-159. http://dx.doi. org/10.1007\%2Fs11010-009-0184-4 